\title{
ANALISIS BUDAYA DAN ETIKA BISNIS DALAM PEMBENTUKAN MANAJEMEN KINERJA KARYAWAN
}

\author{
Phatriakalista Intan Apsari \\ Universitas Muhammadiyah Surabaya \\ Corresponding Author: e-mail : phatriakalista11ipa@gmail.com \\ Isnawati Setyo Putri \\ Universitas Muhammadiyah Surabaya \\ e-mail : putriisnawati6@gmail.com \\ Jihan Abdillah \\ Universitas Muhammadiyah Surabaya \\ e-mail : jihanabdillah378@gmail.com \\ Achmad Majdi Zain \\ Universitas Muhammadiyah Surabaya \\ e-mail : achmadmajdi06@gmail.com \\ Nahzul Abugy Firmansyah \\ Universitas Muhammadiyah Surabaya \\ e-mail : Abugynahzul2017@gmail.com
}

\begin{abstract}
Manufacturing, trading, or service companies have increasingly fierce competition, so based on this fact, a company must have the expertise to manage the company efficiently in order to achieve the planned goals. So one of the things that must be considered by the company is about culture and business ethics. Corporate culture will affect the strength or weakness of the company on performance within a company, as well as ethics. Ethics is needed in any activity, including the business world. This research is the result of qualitative research using library research methodology, which refers to books and scientific works related to business ethics, organizational culture, and corporate culture. The results obtained are that culture contributes to the formation of ethical behavior, because an organizational culture is a combination of values and norms to guide the actions of all company employees. This ethical behavior arises from the rules called business ethics. A strong culture will be a company tool to compete with competitors. Because a strong culture will be able to increase constant behavior, which can create effectiveness within the organization which is certainly influenced by the performance of employees within the company.
\end{abstract}

Keywords: Organizational Culture, Corporate Culture, Business Ethics, Employee Performance.

\section{ABSTRAK}

Perusahaan manufaktur, dagang, atau jasa memiliki persaingan yang semakin ketat, maka berdasarkan fakta tersebut, keahlian untuk mengelola perusahaan secara efisien harus dimiliki oleh sebuah perusahaan agar 
mencapai tujuan yang direncanakan. Maka salah satu hal yang harus diperhatikan oleh perusahaan adalah mengenai Budaya dan etika bisnis. Budaya perusahaan akan berpengaruh terhadap kuat ataupun lemahnya perusahaan terhadap kinerja di dalam sebuah perusahaan, begitu juga dengan etika. Etika dibutuhkan dalam kegiatan apapun termasuk di dunia bisnis. Penelitian ini merupakan hasil penelitian kualitatif menggunakan metedologi penelitian library research, yang merujuk kepada buku-buku dan karya-karya ilmiah yang berkaitan dengan etika bisnis, budaya organisasi, dan budaya perusahaan. Hasil penelitian yang diperoleh yaitu budaya turut andil terhadap pembentukan perilaku yang etis, karena sebuah budaya organisasi merupakan gabungan antara nilai dan norma untuk membimbing tindakan semua karyawan perusahaan. Perilaku etis tersebut timbul dari aturan yang dinamakan etika bisnis. Budaya yang kokoh akan bisa menjadi alat perusahaan untuk berlomba dengan pesaing. Karena dari budaya yang kokoh akan bisa meningkatkan tingkah laku yang konstan, yang mana hal terebut dapat menciptakan keefektifan di dalam organisasi yang tentunya dipengaruhi oleh kinerja karyawan di dalam perusahaan.

Kata Kunci: Budaya Organisasi, Budaya Perusahaan, Etika Bisnis, Kinerja Karyawan.

\section{PENDAHULUAN}

Etika dibutuhkan dalam kegiatan apapun termasuk di dunia bisnis, ketika manusia sudah mulai sadar akan kemajuan di bidang bisnis yang mana hal tersebut menyebabkan manusia semakin jauh dari nilai-nilai Humanistic. Di dalam persaingan bisnis yang ketat, sebuah perusahaan yang unggul bukan saja perusahaan yang hanya mempunyai ukuran bisnis administratif yang baik, akan tetapi perusahaan yang unggul juga wajib memiliki etika bisnis yang baik (Inayah, 2021). Suatu perusahaan atau organisasi didirikan untuk bisa mencapai tujuan bersama. Kesuksesan dalam mencapai tujuan tersebut dapat dilihat dari hasil kinerja perusahaan yang tentunya tidak lepas dari hasil kinerja sumber daya manusia di dalamnya yang dimiliki oleh perusahaan tersebut. Kinerja ialah wajah mengenai tingkat pencapaian atau prestasi suatu program yang dilaksanakan atau platform dalam mewujudkan tujuan dan visi misi perusahaan yang terdapat di dalam perencanaan strategis suatu perusahaan.

Dalam hal membangun dan mengoptimalkan sumber daya manusia yang telah ada, tentunya kita tidak bisa mempunyai kehendak sesuka hati masing-masing. Kita terikat di dalam sebuah aturan antara satu dengan yang lain, dengan lingkungan kita dan tentunya dengan nilai yang mengontrol hubungan ikatan sosial yang diikuti dan dipercaya kebenarannya. Nilai yang harus dijaga agar dapat menjaga kesinambungan dan mengatur hubungan yang baik dan yang buruk di dalam ikatan sosial inilah yang disebut sistem etika (Mashudi, 2018).

Etika bisnis menurut Lawrence, Weber, dan Pirson (2010) memiliki prinsip petunjuk bagi perilaku moral, contohnya yaitu : berperilaku jujur, menepati janji, dan hormat kepada hak orang lain. Prinsip etika bisnis juga 
dikemukakan oleh Caux Round yang meliputi : 1) Tanggung jawab bisnis dari pemegang saham ke pemangku kepentingan (Stakeholder), 2) Pengaruh ekonomi dan sosial dari bisnis dengan tujuan inovasi dan keadilan, 3) Perbuatan bisnis dari hukum yang tercantum, 4) Sikap menghormati aturan, 5) Dukungan bagi perdagangan multirateral, 6) Sikap untuk berperilaku respek terhadap lingkungan alam, dan 7) Menjauhi proses bisnis yang tidak etis (Sunardi, 2018).

Jika diperhatikan, antara perusahaan yang satu dengan perusahaan yang lain pasti memiliki keunikan yang berbeda. Meskipun terdapat perusahaan yang memproduksi dan menghasilkan barang atau penyedia jasa yang sama, tetapi setiap perusahaan pasti mempunyai perbedaan yang menjadi simbol atau nilai dari perusahaan tersebut. Simbol atau nilai itulah yang akan membentuk budaya perusahaan. Dengan terbentuknya budaya perusahaan maka hal tersebut dapat memberikan pengaruh. Karena budaya perusahaan akan berpengaruh terhadap kuat ataupun lemahnya perusahaan terhadap kinerja di dalam sebuah perusahaan. Hal ini disampaikan oleh robin (2006) bahwasannya budaya perusahaan atau budaya organisasi yang dianut akan memberikan pengaruh kuat ataupun lemah, karena sebuah perusahaan yang memiliki budaya kuat maka budaya tersebut akan mempunyai pengaruh yang besar pada perilaku setiap anggota di dalam perusahaan ataupun organisasi tersebut dan budaya akan memberikan stabilitas pada perusahaan (Monalisa, 2019).

Dalam penelitian yang dilakukan oleh Ayu Maretta Maharani dan Rina dengan judul "Analisis Pengaruh Budaya Organisasi Terhadap Penerapan Sistem Pengendalian Internal dan Implikasinya pada Integritas UKM di Bojonegoro" menyimpulkan bahwa budaya organisasi terhadap sistem pengendalian interal memiliki pengaruh yang signifikan. Budaya organisasi dan sistem pengendalian internal ialah satu kesatuan, karena sistem pengendalian internal tidak bisa bergerak dengan baik tanpa dukungan budaya organisasi yang baik pula (Maharani \& Sulistyowati, 2020).

Pada dasarnya setiap orang yang bergabung di dalam sebuah organisasi mempunyai usaha untuk membangun dan menentukan sesuatu yang bisa membantu kepentingan semua pihak yang terlibat supaya bisa menjalankan kegiatannya. Seorang pemimpin mempunyai peran penting dalam membentuk budaya organisasi, karena kebudayaan adalah hasil persepsi. Orang-orang yang terlibat pada suatu organisasi akan mencerna budaya di tempat tersebut melalui proses mengolah informasi oleh kemampuan berpikir dan perasaannya sesuai dengan apa yang mereka lihat dan pahami melalui panca indera atau pengalaman di organisasi tersebut sehingga bisa menjadi contoh atas apa yang akan karyawan lakukan di tempat kerjanya (Hadijaya, 2020).

Oleh karena itu, dari latar belakang di atas, tulisan ini dimaksudkan untuk menjelaskan mengenai analisis budaya dan etika bisnis yang mana setiap sub bab pembahasannya akan menguraikan mengenai definisi budaya, budaya dan etika bisnis, sampai kepada pembahasan pengaruh budaya dalam mendorong pembentukan manajemen kinerja. 


\section{METODE PENELITIAN}

Penelitian ini menggunakan jenis penelitian deskriptif dengan pendekatan yang bersifat kualitatif dan metode yang digunakan dalam penelitian ini menggunakan metode penelitian library research. Library research dipilih karena penulis ingin memberikan deskripsi teori dan hasil temuan-temuan dari pencarian literature yang mempunyai hubungan dengan budaya dan etika bisnis. Metode library research yaitu teknik penelitian dengan mengumpulkan data dan karya tulis ilmiah yang mempunyai kaitan dengan objek pembahasan dalam penelitian atau melakukan kajian mendasar yang dilaksanakan untuk memecahkan sebuah permasalahan yang pada dasarnya bertumpu pada kajian kritis dan secara komprehensif terhadap bahan-bahan pustaka ataupun karya ilmiah lainnya yang relevan dengan penelitian ini. Kajian dari literature yang dipakai merujuk kepada buku-buku dan karya-karya ilmiah yang berkaitan dengan etika bisnis, budaya organisasi, dan budaya perusahaan.

\section{PEMBAHASAN}

A. Definisi Budaya

Terdapat banyak sekali definisi tentang kata budaya atau kebudayaan, bergantung dari sisi mana para ahli mengartikannya. Ras, bangsa, atau etnis sering dihubungkan dengan kata budaya atau kebudayaan di dalam kehidupan sehari-hari. Persepsi kata budaya sangat sulit untuk diartikan, karena kata budaya adalah maya yang mana memiliki banyak makna yang sangat luas dan lengkap. Kata budaya bisa menjamah berbagai aspek kehidupan, baik dari sisi aspek material seperti makanan dan pakaian. Aspek sosial kemasyarakatan, seperti organisasi pemerintahan atau struktur pemerintahan. Aspek perilaku manusia, dan aspek-aspek yang lainnya.

Cinta, dan rasa adalah arti dari kata budi dan daya yang mana itu adalah bentuk umum dari kata budaya. Kata budaya berasal dari bahasa Sansekerta (Budhayah) yang mana itu adalah bentuk umum dari kata buddhi yang artinya akal. Sedangkan didalam bahasa inggris, kata budaya adalah Culture, kemudian dari kata Colera (Bahasa latin) yang artinya Mengelolah, mengerjakan, mengembangkan tanah/bertani (Normina, 2017).

Kebudayaan dan masyarakat tidak bisa hidup terpisah antara satu sama lain, karena di dalam satu kelompok masyarakat pasti terdapat suatu kebudayaan/Budaya. Oleh karena itu, istilah dari kebudayaan dan masyarakat sering diartikan society, yang mana keduanya belum dibedakan satu sama lain. Maka harusnya perbedaan ini diberikan karena arti dari kedua unsur tersebut sering salah makna. Mengerucutkan bahwa kebudayaan dapat dipandang sebagai sebuah cara hidup yang dipelajari dan diharapkan, sama-sama diikuti oleh para anggota di kelompok masyarakat tertentu. Adapun arti budaya (culture) di dalam Kamus Besar Bahasa Indonesia mempunyai arti sebagai adat istiadat, sesuatu hal yang sudah menjadi kebiasaan yang sukar untuk diubah (Sumarto, 2019).

Dari semua pengertian budaya di atas, penulis menyimpulkan bahwa budaya memiliki arti suatu cara untuk hidup yang bisa bertumbuh, berkembang dan dimiliki bersama oleh sekelompok orang yang diwariskan 
dari generasi ke generasi. Banyak unsur yang sulit untuk membentuk budaya termasuk di dalamnya terdapat sistem agama dan politik, bahasa, adat istiadat, pakaian, bangunan, dan karya seni.

\section{B. Budaya dan Etika Bisnis}

Istilah budaya tidak hanya berlaku di lingkungan masyarakat saja, tetapi juga berlaku untuk lingkungan perusahaan. Bagi perusahaan budaya adalah hal yang terpenting karena untuk mengambil keputusan tanpa memperhatikan budaya yang ada di dalam perusahaan tersebut akan menyebabkan efek yang tidak bisa untuk diprediksi. Budaya organisasi akan menjadi ciri tersendiri yang harus dipraktikkan kepada semua anggota organisasi, pemangku kepentingan perusahaan dan tentunya masyarakat luas. Proses terbentuknya budaya tidak bisa secara cepat tetapi butuh waktu dan dukungan faktor-faktor lain seperti rasa komitmen yang kuat dan keteladanan dari para pimpinan. Budaya mempunyai andil yang sangat signifikan terhadap pembentukan karakter yang etis, karena sebuah budaya organisasi setara dengan nilai dan norma untuk menuntun tindakan semua karyawan. Budaya dapat membantu dalam terciptanya perilaku yang etis, dan tentu sebaliknya bisa mendorong kepada karakter yang tidak etis pula.

Perilaku etis tersebut timbul dari aturan yang dinamakan etika bisnis. Etika mempunyai arti nilai dan aturan moral sejuah mana dipraktikkan atau justru tidak dipraktikkan, walaupun memang seharusnya etika itu harus dipraktikkan. Secara etimologi, etika berasal dari bahasa Yunani yaitu ethos yang artinya sikap, kebiasaan, dan cara berpikir (Butarbutar, 2019). Istilah etika sudah dipergunakan oleh Aristoteles yaitu seorang filsuf Yunani untuk memperlihatkan filsafat moral. Jadi, etika adalah pilar, norma dan patokan perilaku yang mana dia mengatur individu ataupun kelompok yang menunjukkan mana yang benar dan mana yang salah. Etika bisnis bisa memberikan batasan kepada para manajer ataupun karyawan perusahaan agar mereka tidak melakukan sesuatu hal yang seharusnya dilarang atau tidak dilakukan. Karena etika bisnis bisa memberikan pengaruh bagaimana sepantasnya perusahaan berhubungan dengan para pekerja atau sebaliknya, dan bagaimana perusahaan tersebut berhubungan dengan para pelaku ekonomi yang lain.

Sementara itu etika bisnis didefinisikan sebagai segmen etika terapan yang mencoba untuk mengontrol aturan moral dan etika dari perusahaan. Etika bisnis juga mencakup seberapa baik atau buruknya usaha dalam membahas permasalahan moral dan etika, dan juga menunjukkan apa yang seharusnya tidak dilakukan di dalam proses mereka. Proses yang dimaksudkan termasuk semua prospek bisnis dari awal produksi sampai pada hal pemasaran (Hasoloan, 2018). Etika bisnis merupakan norma dan ketentuan yang dinilai baik atau buruk dalam menjalankan aktivitas bisnis. Etika bisnis organisasi dapat membentuk karakter pegawai menjadi baik karena setiap menjalankan etika yang baik, maka nantinya akan membawa dampak positif atas hubungan perusahaan dan pelanggan. Merupakan hal penting dalam praktik bisnis, karena bisnis yang baik pastinya didasari pada nilai-nilai etis yang terkandung di dalam etika bisnis (Winardi, 2020). 


\section{Model Manajemen Kinerja}

Definisi dari Manajemen Kinerja adalah proses untuk memastikan hasil dari kinerja karyawan sesuai dengan tujuan organisasi atau perusahaan, sehingga dengan mengetahui hasil kinerja perusahaan maka perusahaan dapat memperoleh keuntungan yang kompetitif (Sudadi \& Sugiyanto, 2021). Terdapat beberapa model manajemen kinerja yang bisa digunakan oleh perusahaan, salah satunya yaitu (Utomo, Hariyono, Prabowo, \& Ikatrinasari, 2020) :

- Model Deming

Yang mana merupakan proses manajemen yang dimulai dengan penyusunan rencana, melaksanakan tindakan, monitoring hasil pelaksanaan, dan yang terakhir evaluasi atau meninjau kembali jalannya kegiatan.

- Model Torrington dan Hal

Model ini merinci terlebih dahulu hasil yang ingin dicapai dari suatu pekerjaan. Kemudian menentukan dukungan yang diberikan kepada kinerja agar mencapai sebuah tujuan yang diharapkan. Untuk model ini, pelaksanaan dari kinerja ditinjau kembali dan dinilai yang kemudian selanjutnya bisa melakukan pengelolaan atas kinerja tersebut.

- Model Studi Pustaka

Mempelajari dokumen, buku, dan jurnal yang terkait dengan problem yang sedang diamati adalah cara yang digunakan oleh model studi pustaka. Yang kemudian dilakukan analisis dengan menyusun data yang terkait dan memilih data yang terkait dengan tujuan. Dari model ini hasil yang didapat diharapkan akan mampu memberikan gambaran dengan penerapan model manajamen kinerja karyawan yang dilakukan.

D. Pengaruh Budaya dalam Mendorong Pembentukan Manajemen Kinerja

Menurut Rivai dan Mulyadi (2012), pengertian budaya adalah sekumpulan pemahaman seperti aturan, nilai, dan sikap yang dimiliki bersama oleh anggota organisasi. Sedangkan arti organisasi menurut Laudon (2012) ialah struktur formal stabil yang mengambil sumber daya dari lingkungan dan memproses untuk menghasilkan sesuatu dalam jangka pendek ataupun jangka panjang (Sunarsi \& Yuliani, 2019).

Dapat penulis simpulkan bahwa budaya organisasi adalah sebutan yang digunakan untuk membuat rangkaian variabel perilaku yang memiliki acuan pada nilai-nilai dan prinsip pokok yang mempunyai peran sebagai dasar bagi sistem manajemen organisasi.

Atau budaya organisasi bisa diartikan dengan suatu gambaran dasar yang ditingkatkan oleh suatu kelompok seperti mempelajari pencegahan permasalahan, diakui secara sah, yang sudah berjalan baik, dan hal tersebut harus dipikirkan oleh anggota baru sebagai dasar atau cara yang benar untuk dipikirkan dan dipraktikkan dalam hubungan-hubungannya dengan masalah yang ada. Adapun fungsi dari budaya organisasi adalah sebagai berikut (Munawirsyah, 2018) : 
a. Give members an organizational identity (Memberikan anggota identitas organisasi),

b. Facilitate collective commitment (Memfasilitasi komitmen bersama),

c. Promote social system stability (Meningkatkan stabilitas sistem sosial),

d. Shape behavior by helping members make sense of their surrroundings (Membentuk perilaku dengan membantu anggota memahami lingkungan mereka).

Sedangkan pengertian Budaya perusahaan yaitu sistem nilai bersama yang mempunyai peran sebagai tingkatan begaimana seorang karyawan melakukan kegiatan dalam mencapai tujuan organisasi. Perusahaan digambarkan sebagai tempat untuk memperoleh penghasilan melalui penjualan produk ataupun menawarkan jasa. Proses untuk mendirikan perusahaan dapat dilakukan secara perorangan atau lebih dari satu orang. Di dalam perusahaan keberagaman penilaian kinerja dapat diatasi dengan budaya perusahaan. Indikator budaya perusahaan memiliki hakikat budaya. Salah satunya adalah inovasi dalam pengendalian resiko, dimensi tersebut berkaitan dengan dukungan atau pemberian penghargaan terhadap aspirasi karyawan. Dimensi lain yaitu perhatian yang mengarah pada evaluasi hasil kerja. Di sisi lain orientasi tim yang memiliki titik berat pada kerjasama, dapat menggambarkan kemampuan individu dalam berkoordinasi antara satu dengan yang lainnya (Widijaya \& Noverianto, 2021).

Budaya yang kokoh bisa menjadi alat perusahaan untuk berlomba dengan para kompetitor. Karena budaya yang kokoh akan mampu menumbuhkan sikap yang konsisten yang bisa meningkatkan keefektifan perusahaan yang tentunya juga dipengaruhi oleh kinerja pegawai. Sebaliknya, jika budaya tidak kokoh maka impian dan tujuan perusahaan akan bergerak ke arah yang salah. Jika budaya organisasi tidak memberi dampak baik bagi organisasi, maka akan mempunyai dampak sebaliknya yaitu dampak buruk bagi kinerja organisasi. Karena budaya itu sendiri akan memberitahukan atau meluruskan kepada para pegawai tentang bagaimana sikap mereka yang seharusnya dilakukan (Metris, Mutmainah, Alvin, \& Fauzan, 2021). Budaya organisasi menjadi label bagi organisasi atau perusahaan tersebut, yang mana akan memberikan pengaruh bagaimana perilaku orang-orang didalamnya. Sehingga jika perusahaan atau organisasi memiliki budaya yang baik maka tidak perlu heran jika orang-orang yang berkontribusi di dalamnya adalah orang-orang yang baik dan berkualitas.

\section{PENUTUP}

Berdasarkan pembahasan yang telah dipaparkan di atas maka dapat dikemukakan kesimpulan bahwa budaya adalah suatu cara hidup yang berkembang, bertumbuh dan dimiliki bersama oleh sebuah kelompok orang yang diwariskan dari generasi ke generasi berikutnya. Sementara pengertian dari budaya organisasi sendiri merujuk pada pengertian umum yang digunakan untuk membuat rangkaian variabel yang memiliki acuan pada nilai-nilai, kepercayaan dan prinsip pokok sebagai dasar bagi suatu 
sistem manajamen organisasi. Setiap perusahaan memiliki budaya yang berbeda, tentunya masing-masing memiliki filosofi sendiri-sendiri. Budaya memberikan peran yang penting terhadap pembentukan tingkah laku yang baik, karena sebuah budaya organisasi merupakan sepasang nilai dan norma untuk menuntun tindakan semua karyawan. Budaya dapat memberikan dorongan agar terciptanya perilaku yang baik, dan tentu sebaliknya bisa mengarahkan kepada perilaku yang tidak baik pula. Perilaku etis tersebut timbul dari aturan yang dinamakan etika bisnis. Etika merupakan pilar, norma dan patokan perilaku yang mana dia mengatur individu ataupun kelompok yang menunjukkan mana yang benar dan mana yang salah. Oleh karena itu baik budaya maupun etika bisnis adalah hal yang tidak bisa dipisahkan.

Budaya menjadi hal yang urgent di dalam perusahaan, karena pada dasarnya budaya yang kokoh akan menjadi alat perusahaan untuk bersaing dengan kompetitor. Karena dari budaya yang kuat akan dapat menumbuhkan perilaku yang konstan yang dapat menciptakan keefektifan organisasi yang dipengaruhi oleh kinerja karyawan di dalam perusahaan. Sedangkan apabila budaya tidak memiliki fondasi yang kokoh, maka tujuan dari perusahaan tentunya akan bergerak ke arah yang salah.

Sejalan dengan kesimpulan yang telah dibuat, maka saran yang dapat penulis berikan kepada stakeholder adalah berkaitan dengan budaya organisasi, perusahaan perlu lebih intens dan memperkuat budaya organisasi yang ada di dalam perusahaan dengan tujuan untuk meningkatkan kinerja perusahaan. Karena harapannya, implementasi budaya organisasi bisa lebih kuat lagi sehingga benar-benar tertanam pada jiwa seorang karyawan. Budaya pada perusahaan perlu dikenalkan kepada semua oknum yang mempunyai tanggung jawab di dalam perusahaan, agar tetap terjaga dalam memberikan pelayanan yang baik kepada para pelanggan ataupun konsumen.

\section{DAFTAR PUSTAKA}

Butarbutar, B. (2019). Peranan Etika Bisnis Dalam Bisnis. Jurnal Ilmu Manajemen Terapan, 1(1), 187-195. https://doi.org/10.31933/JIMT

Hadijaya, Y. (2020). Budaya Organisasi. Medan: CV. Pusdikra Mitra Jaya. Retrieved from https:/ / books.google.co.id/books?hl=id\&lr=\&id=_zOrEAAAQBAJ\&oi=fnd $\& p g=$ PP2\&dq=Membentuk+Pola+Manajemen+Kinerja + melalui+budaya $+b$ isnis\&ots $=$ TsOXEc-

VUE\&sig=voFFz5rKX1tVUtgALt9fKJlJDak\&redir_esc=y\#v=onepage\&q\&f $=$ false

Hasoloan, A. (2018). Peranan Etika Bisnis Dalam Perusahaan Bisnis. Jurnal Warta, (57), 1-10. Retrieved from http://jurnal.dharmawangsa.ac.id/index.php/juwarta/article/view/14 1

Inayah, L. L. (2021). Implementasi Etika Bisnis Islam dan Dampaknya Terhadap Budaya Kerja Karyawan di BMT UAS Senori Kabupaten Tuban. Journal of Islamic Banking, 2(1), 96-129.

Maharani, A. M., \& Sulistyowati, R. (2020). Analisis Pengaruh Budaya 
Organisasi Terhadap Penerapan Sistem Pengendalian Internal Dan Implikasinya Pada Integritas UKM Di Bojonegoro. Artikel Akuntansi, Auditing Dan Keuangan Vokasi, 04(02), 157-172.

Mashudi. (2018). Perilaku Dan Budaya Konsumen Madura Dalam Dinamika Etika Bisnis Syariah. Al-Insyiroh: Jurnal Studi Keislaman, 2(1), 145-161. https://doi.org/10.35309/alinsyiroh.v2i2.3326

Metris, D., Mutmainah, E. S., Alvin, \& Fauzan, A. (2021). PERBAIKAN KINERJA MELALUI BUDAYA ORGANISASI DAN KUALITAS SUMBER DAYA MANUSIA. Perwira Journal of Economics and Business (PJEB), 1(2), 86-92.

Monalisa, C. (2019). Pengaruh Budaya Organisasi dan Motivasi Terhadap Prestasi Kerja Pegawai Inspektorat Kabupaten Konawe Utara. Jurnal Ilmu Manajemen, 5(1), 18-29.

Munawirsyah, I. (2018). PENGARUH MOTIVASI KERJA DAN BUDAYA ORGANISASI TERHADAP KINERJA KARYAWAN PADA PT. PERKEBUNAN NUSANTARA III MEDAN. Jurnal Bisis Administrasi, O7(02), 33-39.

Normina. (2017). Pendidikan dalam kebudayaan. Ittihad Jurnal Kopertais Wilayah XI Kalimantan, 15(28), 17-28.

Sudadi, \& Sugiyanto. (2021). MANAJEMEN KINERJA BERBASIS BUDAYA RELIGIUS DALAM MENINGKATKAN PROFESIONALISME GURU DI MA MAMBAUL ULUM TUNJUNGMULI KECAMATAN RAKIT KABUPATEN BANJARNEGARA. Jurnal Inspirasi, 5(2), 166-194.

Sumarto. (2019). Budaya, Pemahaman dan Penerapannya "Aspek Sistem Religi, Bahasa, Pengetahuan, Sosial, Keseninan dan Teknologi". Jurnal Literasiologi, $1(2)$,

144-159. https://doi.org/10.47783/literasiologi.v1i2.49

Sunardi. (2018). Etika Bisnis, Budaya Organisasi, Corporate Governance , Kinerja Perusahaan Dan Komitmen Organisasi. BALANCE Jurnal Akuntansi Dan Bisnis, 2(1), 131-139. https://doi.org/10.32502/jab.v2i1.1166

Sunarsi, D., \& Yuliani, I. (2019). PENGARUH GAYA KEPE MIMPINAN DAN BUDAYA ORGANISASI TERHADAP KINERJA KARYAWAN PADA BANK BTN KANTOR CABANG TANGERANG. Semarak, 2(1), 21-30.

Utomo, U., Hariyono, H., Prabowo, R. F., \& Ikatrinasari, Z. F. (2020). Analisis Implementasi Model Manajemen Kinerja Karyawan Pada Industri Steel Casting (Studi Kasus PT. MB Indonesia). Journal Industrial Servicess, 5(2), 213-219. https://doi.org/10.36055/jiss.v5i2.8002

Widijaya, \& Noverianto, R. (2021). Pengaruh Budaya Perusahaan Terhadap Kinerja Perusahaan. Conference on Management, Business, Innovation, Education and Social Science, 1(1), 1712-1723.

Winardi, W. (2020). ETIKA BISNIS PADA PT. BANK MANDIRI (PERSERO) TBK. JEMSI(Jurnal Ekonomi Dan Manajemen Sistem Informasi, 1(4), 341355. https://doi.org/10.31933/JEMSI 